\title{
Metals and selenium as bioindicators of geographic and trophic segregation in giant petrels Macronectes spp.
}

\author{
Jacob González-Solís ${ }^{1,2, *}$, Carola Sanpera ${ }^{1}$, Xavier Ruiz ${ }^{1}$ \\ ${ }^{1}$ Dept Biologia Animal (Vertebrats), Universitat de Barcelona, Av. Diagonal 645, Barcelona 08028, Spain \\ ${ }^{2}$ British Antarctic Survey, Natural Environment Research Council, High Cross, Madingley Road, Cambridge CB3 0ET, \\ United Kingdom
}

\begin{abstract}
We analysed concentrations of cadmium, lead, mercury and selenium in blood from males and females of the 2 sibling species of giant petrels, the northern Macronectes halli and the southern M. giganteus, breeding sympatrically at Bird Island (South Georgia, Antarctica). Blood samples were collected in 1998 during the incubation period, from 5 November to 10 December. Between species, cadmium and lead concentrations were significantly higher for northern than for southern giant petrels, which probably resulted from northern giant petrels wintering in more polluted areas (mainly on the Patagonian Shelf and Falkland Islands) compared to southern giant petrels (wintering mainly around South Georgia and the South Sandwich Islands). Between sexes, cadmium concentrations were significantly higher for females than for males in both species, corresponding to the more pelagic habits of females compared to the more scavenging habits of males. Lead and cadmium concentrations in circulating blood decreased significantly over the incubation period, suggesting that when breeding at Bird Island, exposure to the source of pollution had ended, and these metals had been cleared from the blood and excreted, or rapidly transferred to other tissues. Association of lead and cadmium with a common source of pollution was further corroborated by a significant positive correlation between the levels of the 2 elements found. Mercury levels were similar between the species, but showed an opposite trend between sexes, with males showing higher levels than females in northern giant petrels, and the opposite was true in southern giant petrels, with no changes throughout incubation. Selenium levels were similar between sexes, but significantly greater for northern than for southern giant petrels. Moreover, there was a significant increase in the selenium levels over the incubation period in northern giant petrels. Age of adult birds did not affect metal concentrations. Coefficients of variation of metal levels were consistently lower for northern than for southern giant petrels, particularly for mercury, suggesting that the former species is more dietary specialised than the latter. Contaminant analyses, when combined with accurate information on seabird movements, obtained through geolocation or satellite tracking, help us to understand geographic variation of pollution in the marine environment.
\end{abstract}

KEY WORDS: Environmental contaminants · Chemicals · Sexual dimorphism · Marine pollution · Cadmium $\cdot$ Lead $\cdot$ Mercury

\section{INTRODUCTION}

Concerns about possible adverse effects of pollutants on marine organisms have lead to the study of geo-

*Present address: Dept Biologia Animal (Vertebrats), Universitat de Barcelona, Av. Diagonal 645, Barcelona 08028, Spain. Email: jacob@bio.ub.es graphical and temporal variation of pollution in the marine environment (Thompson 1990). Seabirds are recognised as integrators over space and time for contaminant levels in the marine environment (Walsh 1990, Furness 1993, Braune et al. 2001). Accordingly, contaminant levels in seabirds are increasingly being measured and a growing number of studies are available for monitoring pollution. Albatrosses and petrels are 
suitable to monitor background levels of pollution over large areas, given their extreme mobility (Weimerskirch \& Robertson 1994b, Weimerskirch et al. 1994a, Prince et al. 1998, Klomp \& Schultz 2000). However, comparisons over time and space are difficult given the confounding effects of other factors, such as the species and tissue sampled, which influence pollutant concentrations. Whereas seasonal or historical changes in the same location are easier to monitor, the establishment of baseline levels of contamination over wide areas is difficult because it usually requires simultaneous sampling of the same seabird and tissue at several distant locations. Metal exposure in birds is thought to be mainly through the ingestion of food, thus providing information on the contamination levels from the whole food chain (Furness 1993). Accordingly, diet differences have been used to explain metal levels in interspecific studies from the same locality (e.g. Monteiro et al. 1998, Stewart et al. 1999) or intraspecific differences between localities (Sanpera et al. 2000). However, metal concentrations may also show interspecific differences according to metabolism, breeding and moult schedules, life-history strategies and other factors (Walsh 1990), which may confound unequivocal interpretations. The detailed study of seabird movement, however, can provide new insights into the geographical variation of pollutants.

Currently, the use of satellite tracking and light-level geolocation can give accurate information on the areas exploited by a pelagic seabird, also according to gender or age class (e.g. Prince et al. 1998, Waugh et al. 1999, González-Solís et al. 2001). This allows for more critical comparisons in contaminant levels between areas as well as indicating the location of particularly polluted distant areas. For instance, although subantarctic archipelagos are relatively pristine areas, seabirds breeding there often forage or winter thousands of kilometres offshore (Croxall \& Wood 2002), thus providing an opportunity to assess not only the increasing influence of anthropogenic pollutants on remote areas by, e.g., atmospheric transport, but also the influence on pelagic seabirds of trips to distant polluted areas.

In this study, we analysed blood samples to study the metal and selenium levels of the 2 species of giant petrels breeding at Bird Island: the northern Macronectes halli, and the southern $M$. giganteus. Metal levels in blood samples reflect mainly short-term exposure through diet and other contributing physiological factors. Bird blood has proven to be a suitable matrix for monitoring mercury in the marine environment (Furness 1993, Kahle \& Becker 1999). Northern and southern giant petrels are closely related and highly morphologically similar, meaning that intersexual differences in size are more conspicuous than interspe- cific ones, with males being about $25 \%$ heavier than females (González-Solís et al. 2000a). Both species show a substantial overlap in resource utilisation during the breeding season, being the dominant scavengers in subantarctic and Antarctic waters and able to cover vast distances in few days (Hunter 1985, González-Solís et al. 2002). However, whereas both males and females feed on fur seal and penguin carrion, females show more pelagic habits and also feed extensively on marine prey (Hunter 1983, González-Solís et al. 2000a). The sexual segregation in food resources allows for the study of the influence of diet on the contaminant levels in the same species, thus ruling out interspecific confounding factors. Moreover, despite the similarities in ecology between the 2 giant petrel species, there is spatial segregation in the foraging and wintering areas between them (González-Solís et al. $2000 \mathrm{~b}, 2001)$. These differences provide a singular opportunity to study the influence of pollution from remote areas on the contamination levels of 2 sibling species at the same breeding locality. Moreover, understanding the pollution sources for giant petrels is particularly relevant to the current concerns over their conservation (Rootes 1988, Jouventin \& Weimerskirch 1990, Woehler \& Johnstone 1991, SCAR 1992). Southern giant petrels are currently recognised as globally threatened (vulnerable) and northern giant petrels are regarded as near threatened according to IUCN criteria (BirdLife International 2000).

Our aims in this study were, therefore, to: (1) characterise the levels of metals and selenium in the blood of giant petrels breeding in a relatively pristine area, such as the subantarctic archipelago of South Georgia; (2) relate selenium and metal levels to differential exposure due to the geographical partitioning in foraging and wintering areas between the 2 species; (3) relate selenium and metal levels to sexual segregation in food resources; and (4) evaluate the potential vulnerability of giant petrels to metal and selenium contamination according to species and gender.

\section{MATERIALS AND METHODS}

Fieldwork was undertaken on Bird Island, South Georgia $\left(54^{\circ} 03^{\prime} \mathrm{S}, 38^{\circ} 36^{\prime} \mathrm{W}\right)$ between 5 November and 10 December 1998. Blood samples were taken from breeding adults over the incubation period, which at Bird Island extends on average from 20 September to 10 December for the northern giant petrel and from 30 October to 20 January for the southern giant petrel. We caught birds on their nests, took 1 blood sample per bird of $1 \mathrm{ml}$ from the leg vein, and preserved the sample in a tube $(2 \mathrm{ml}$ vial $)$ with absolute alcohol at room temperature until analysis. We sexed 
the study birds of both species by culmen length measurement and confirmed the assigned sex with reference to the sex of its partner (Hunter 1987, GonzálezSolís et al. 2000a). The age of the adults was known because they were ringed as chicks.

Chemical determination of heavy metals (mercury, lead, cadmium) and selenium was carried out by means of ICP-OES (Scientific Technical Services of Barcelona University), Perkin-Elmer Optima 3200 RL (Serveis Científico-Técnics, University of Barcelona). Dried blood samples (5 to $50 \mathrm{mg}$ ) were digested in QXP-1500 quartz containers using $\mathrm{HNO}_{3}$ (1 to $\left.2 \mathrm{ml}\right)$ and $\mathrm{H}_{2} \mathrm{O}_{2}(0.5$ to $1 \mathrm{ml}$ ) in a microwave oven. Accuracy of analysis was checked by measuring certified reference tissue (human whole blood, Seronorm Trace Elements, SERONORM MR9067). Mean recoveries were 98 to $100 \%$ and no corrections were done.

Since metal concentrations did not approach normality, medians between groups were compared by Mann-Whitney $U$-tests and associations between variables were tested by Spearman rank correlations. Medians and ranges of metal concentrations are given in figures in $\mu \mathrm{g} \mathrm{g} \mathrm{g}^{-1}$ dry wt, but in addition, concentration levels are reported in Table 1 as mean \pm SD for comparison purposes. All tests are 2-tailed and significance level was set to $\mathrm{p}<0.05$.

\section{RESULTS}

\section{Metal concentration in blood}

Concentration levels in blood for cadmium, lead, mercury and selenium are shown in relation to sex and species in Fig. 1 and Table 1. Cadmium concentration was significantly greater for females than for males in both species (northern giant petrels, Mann-Whitney $U$-test, $Z=-2.5, \mathrm{p}=0.011$; southern giant petrels, MannWhitney $U$-test, $Z=-3.3, \mathrm{p}=0.001$; Fig. 1, Table 1), and significantly greater for northern than for southern giant petrels (Mann-Whitney $U$-test, $Z=-3.6, \mathrm{p}<0.001$ ).

Lead concentration was greater for northern giant petrel females than for males, though the difference was only marginally significant (Mann-Whitney $U$-test, $Z=-1.9, \mathrm{p}=0.055)$. In contrast, lead levels were very similar between sexes in southern giant petrels (MannWhitney $U$-test, $Z=-0.09, \mathrm{p}=0.93$; Fig. 1, Table 1). Between the 2 species, lead concentrations were greater for northern than for southern giant petrels (Mann-Whitney $U$-test, $Z=-3.7, \mathrm{p}<0.001$ ).

Mercury concentration for males and females showed a contrasting pattern between northern and southern giant petrels. It was significantly lower for northern giant petrel females than for males (MannWhitney $U$-test, $Z=-1.9, \mathrm{p}=0.05$ ), but the opposite was

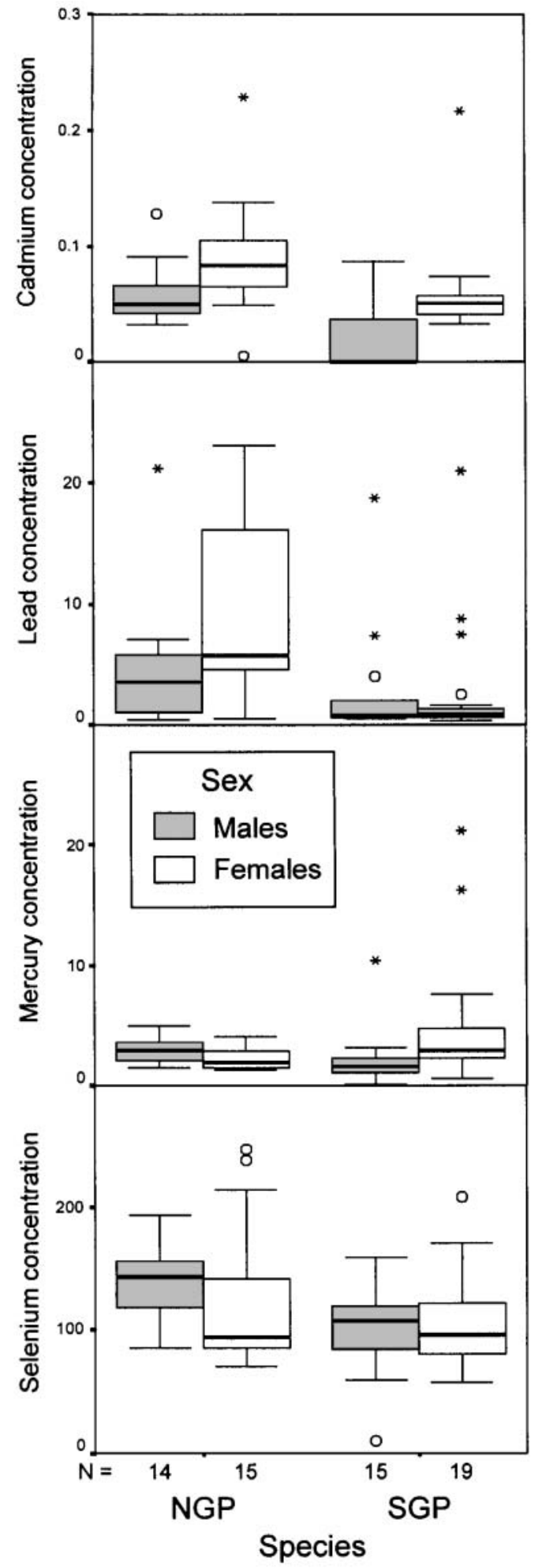

Fig. 1. Macronectes spp. Median concentrations $\left(\mu \mathrm{g} \mathrm{g}^{-1}\right.$ dry wt) of cadmium, lead, mercury and selenium in the blood of incubating giant petrels, according to gender and species. $\mathrm{NGP}=$ northern giant petrel; $\mathrm{SGP}=$ southern giant petrel * : extreme values; O: outlier values; boxes represent interquartile range; bars represent \pm range, excluding extreme and outlier values 
true for southern giant petrel females and males (MannWhitney $U$-test, $Z=-3.1, \mathrm{p}=0.002$; Fig. 1, Table 1). Between the 2 species, however, mercury concentration was very similar when data from males and females were pooled (Mann-Whitney $U$-test, $Z=0.00, \mathrm{p}=1$ ).

Median selenium concentration was slightly greater for males than for females in both species, though not significantly (northern giant petrels, Mann-Whitney $U$-test, $Z=-1.6, \mathrm{p}=0.12$; southern giant petrels, MannWhitney $U$-test, $Z=-0.5, \mathrm{p}=0.64$; Fig. 1). Between the 2 species, however, selenium concentration was significantly greater for northern than for southern giant petrels (Mann-Whitney $U$-test, $Z=-2.3, \mathrm{p}=0.019$ ).

\section{Metal concentration in relation to sampling date}

Giant petrels were blood sampled during the incubation period between 5 November and 10 December. Given that blood is a dynamic tissue, we tested potential associations between metal concentrations and sampling date by a Spearman correlation test. Since in most cases males and females showed the same trends (Fig. 2), sex data were pooled. Northern giant petrels showed a significant decrease in cadmium and lead concentration as well as an increase in selenium concentration over the incubation period (Fig. 2). Southern giant petrels showed a significant decrease in lead concentration (Fig. 2), with no changes to cadmium or selenium concentrations.

\section{Metal concentration in relation to adult age}

The mean age $( \pm \mathrm{SD})$ for the northern giant petrels sampled was $17.2 \pm 5.8 \mathrm{yr}(\mathrm{n}=34)$ and for southern giant petrels was $19.9 \pm 8.3 \mathrm{yr}(\mathrm{n}=29)$. We correlated metal concentrations for each species with age, but no significant relationship emerged (northern giant petrels: cadmium $\mathrm{r}_{\mathrm{s}}=-0.19, \mathrm{p}=0.32$; lead $\mathrm{r}_{\mathrm{s}}=-0.21$, $\mathrm{p}=0.27$; mercury $\mathrm{r}_{\mathrm{s}}=0.02, \mathrm{p}=0.89$; selenium $\mathrm{r}_{\mathrm{s}}=0.02$ ， $\mathrm{p}=0.93$; southern giant petrels: cadmium $\mathrm{r}_{\mathrm{s}}=-0.16$, $\mathrm{p}=0.36$; lead $\mathrm{r}_{\mathrm{s}}=-0.18, \mathrm{p}=0.32 ;$ mercury $\mathrm{r}_{\mathrm{s}}=-0.03$, $\mathrm{p}=0.85$; selenium $\mathrm{r}_{\mathrm{s}}=0.02, \mathrm{p}=0.93$ ).

\section{Correlation between metal concentrations}

Both northern and southern giant petrels showed a highly significant positive correlation between cadmium and lead concentrations (northern giant petrels: $r_{\mathrm{s}}=0.71, \mathrm{p}<0.001$; southern giant petrels: $\left.r_{s}=0.42, p=0.01\right)$. Moreover, northern giant petrels also showed a negative correlation of selenium with lead and cadmium, though only marginally significant with cadmium (selenium-lead correlation: $\mathrm{r}_{\mathrm{s}}=-0.52, \mathrm{p}<0.01$; selenium-cadmium correlation: $\left.r_{s}=-0.52, p=0.06\right)$. The other metal concentrations were not significantly correlated (all p > 0.15), including the relationship between mercury and selenium, sometimes reported as significant in other studies (Norheim 1987).
Table 1. Macronectes spp. Mean metal concentration ( $\mu \mathrm{g} \mathrm{g}^{-1}$ dry wt) in blood of incubating giant petrels (GP) at Bird Island, according to species and gender. SD: standard deviation; CV: coefficient of variation; M: male; F: female

\begin{tabular}{|lcccc|}
\hline Element & $\begin{array}{c}\text { Northern GP } \\
\mathrm{M}(\mathrm{N}=14)\end{array}$ & $\begin{array}{c}\text { Northern GP } \\
\mathrm{F}(\mathrm{N}=15)\end{array}$ & $\begin{array}{c}\text { Southern GP } \\
\mathrm{M}(\mathrm{N}=15)\end{array}$ & $\begin{array}{c}\text { Southern GP } \\
\mathrm{F}(\mathrm{N}=19)\end{array}$ \\
\hline Cadmium & & & & \\
Mean & 0.059 & 0.089 & 0.020 & 0.059 \\
SD & 0.025 & 0.050 & 0.032 & 0.040 \\
CV $(\%)$ & 42 & 56 & 160 & 67 \\
Lead & & & & \\
Mean & 4.682 & 9.867 & 2.728 & 2.731 \\
SD & 5.286 & 7.876 & 4.805 & 5.002 \\
CV $(\%)$ & 112 & 79 & 176 & 183 \\
Mercury & & & & 4.946 \\
Mean & 2.943 & 2.258 & 2.160 & 5.163 \\
SD & 0.976 & 0.903 & 2.413 & 104 \\
CV (\%) & 33 & 40 & 112 & 104.580 \\
Selenium & & & & 37.521 \\
Mean & 136.797 & 125.972 & 101.632 & 36 \\
SD & 28.522 & 60.734 & 35.980 & \\
CV (\%) & 21 & 48 & 35 & \\
\end{tabular}

\section{DISCUSSION}

\section{Interspecific differences}

The 2 species of giant petrels are closely related and show similar ecology. Giant petrels are able to cover vast distances in few days, potentially interacting with inshore polluted areas far from the breeding site (GonzálezSolís et al. 2000a, 2002). Despite the ecological similarities between the 2 species, northern giant petrels winter mainly on the Patagonian Shelf (around the Falklands Islands). During incubation females tend to forage north and east of South Georgia, often close to or on the Patagonian Shelf, whereas males forage mainly around the South Georgia Archipelago. In contrast, the wintering area of southern giant petrels is more restricted to South Georgia and the neighbouring 

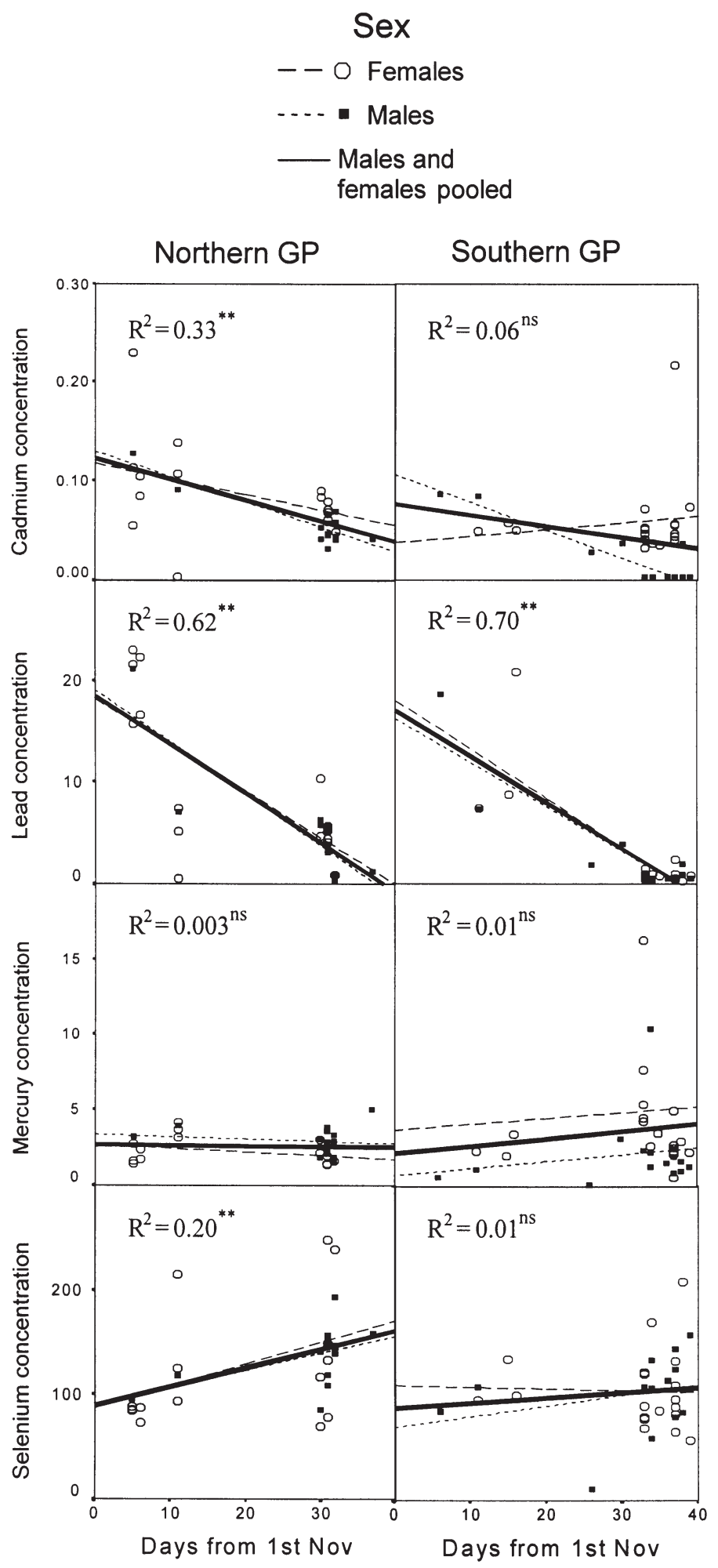

Fig. 2. Macronectes spp. Cadmium, lead, mercury and selenium values in relation to the sampling date (1998) for males and females of northern (left panel) and southern (right panel) giant petrels. ${ }^{* *} \mathrm{p}<0.01$; ns: non-significant. $\mathrm{R}^{2}$ and significance refers to males and females pooled. Highest value for mercury in southern giant petrel females is not shown
South Sandwich Islands and, during incubation, their foraging trips are mainly south and west of South Georgia (González-Solís et al. 2000a, 2001). These differences provide a unique opportunity to study the potential influence of pollution over each area on metal and selenium levels in each species. Blood samples taken during incubation showed significantly higher concentrations of cadmium and lead in northern compared to southern giant petrels. Blood is a dynamic tissue, so metals are usually mobilised from the bloodstream to the organs, fat or bone in a period that can extend from few weeks to few months. Thus, metal levels in circulating blood should reflect recent exposure to the source of pollution through diet or accumulated metals mobilised from reserves to the blood (Furness 1993, Kahle \& Becker 1999). Thus, higher levels of cadmium and lead in northern giant petrels reflect the higher pollution levels in Patagonia compared to South Georgia and surrounding areas. That is, the Patagonian Shelf is a nearshore environment polluted by discharges from riverine transport, offshore oil operations and high shipping activity. For instance, unusually high levels of cadmium in the squid Illex argentinus in northern Patagonia have been reported (Gerpe et al. 2000). The Patagonian shelf actually sustains one of the largest squid fisheries in the world (Rodhouse et al. 2001) and squid is likely to form part of the northern giant petrel diet during winter. South Georgia, however, can be considered a relatively pristine area contaminated mainly by atmospheric transport.

We also found a decrease in cadmium and lead concentrations in blood, associated with the progress of the incubation period. This decline can be expected once exposure to pollutants has decreased, since metals in circulating blood would be stored in other tissues. The decrease is consistent with the acquisition of cadmium and lead mainly while foraging far away from South Georgia during winter months.

The rapid increase of selenium in the blood of northern giant petrels but not in southern giant petrels during the incubation period suggests that the origin of this metalloid may be in the local environment, perhaps through the consumption of a selenium rich resource eaten more extensively by northern than southern giant petrels.

Coefficients of variation of metal levels in blood were consistently lower in northern than in southern giant petrels in both sexes (Table 1). The difference was particularly striking in mercury levels, therefore greater in southern than northern giant petrels. These differences may be linked to differences in dietary specialisation between the 2 species (Bearhop et al. 2000). The lower variability in mercury concentrations in northern giant petrels suggests that this species may be more specialised in diet than southern giant petrels, though 
historical diet analysis did not recognise important differences between the 2 species, apart from a greater utilisation of fur seal carrion by northern giant petrels (Hunter 1985).

\section{Intersexual differences}

We found higher concentrations of cadmium in females than males in both species, supporting results of previous observations on petrel diet and attendance at seal carcasses. At least during the breeding season, males feed mainly on penguin and seal carcasses on shore while females forage at sea taking a higher proportion of krill, squid and fish than males (Hunter 1983, Hunter \& Brooke 1992, González-Solís et al. 2000a). Krill and particularly cephalopods generally contain high levels of cadmium (Honda et al. 1987, Gerpe et al. 2000), and thus seabird and cetacean species feeding more extensively on these taxa usually show higher levels of cadmium (Muirhead \& Furness 1988, Thompson 1990, Bowles 1999, Stewart et al. 1999). In contrast, although Antarctic fur seals Arctocephalus gazella seem to accumulate important quantities of cadmium in the liver (Malcolm et al. 1994), carrion (muscle) from this species shows low levels of this metal (de Moreno et al. 1997).

With regard to mercury, a contrasting gender-pattern was observed between northern and southern giant petrels. Dynamics of mercury in the bloodstream are influenced by several factors, particularly intake through diet, excretion through moulting and in females, excretion by egg laying (Lewis et al. 1993, Monteiro \& Furness 2001). Mercury levels in body feathers were found to be higher in female northern giant petrels, which was related to a greater consumption of marine prey by females as opposed to a more carrion-based diet in males (Becker et al. 2002). Mercury levels obtained in the blood of southern giant petrels reflect these results. However, the reversed trend in males females of northern giant petrels does not match the pattern found in feathers. We do not know the cause for this reversed trend, but the higher levels of mercury concentration in northern giant petrel males coinciding with an early-moulting schedule for this group suggest a possible relationship between a temporal increase of mercury concentration in blood and mercury excretion through the moult period. That is, in both northern and southern giant petrels, wing moult starts at the end of the incubation period, partially coinciding with the second part of the sampling period, but northern giant petrel males moult some weeks before the rest (Hunter 1984). Apparently, mercury is stored in some internal tissues, mainly liver and kidney, until it is excreted mostly through moulting feathers (Stewart et al. 1994,
Monteiro \& Furness 1995). Thus, the mobilisation of mercury from internal tissues to feathers might produce a temporal increase of mercury levels in blood and may explain, to some extent, the increase in the levels of mercury in the blood of the early-moulting northern giant petrel males as compared to the rest of the groups.

\section{Vulnerability to metals and selenium}

Comparisons of metal levels in blood with other seabirds is difficult given the scarcity of data and the heterogeneity of units in which data are reported. Nevertheless, in general, levels of lead and mercury in giant petrels appear to be high, and levels of selenium extremely high, when compared to other birds (Franson 1996, Heinz 1996, Pain 1996, Burger \& Gochfeld 1997, 2002, Bearhop et al. 2000). Levels of mercury and selenium in tissues and feathers of giant petrels have also been reported to be high when compared to other species of seabirds (Kim et al. 1996). Although the relationship between mercury and selenium in seabirds is not as straightforward as in marine mammals, in which a 1:1 molar basis has been found, this does not constitute evidence that a protective effect of selenium against mercury is not operating. In fact, a selenium surplus in relation to mercury (on a molar basis) in various tissues of Arctic seabirds has been reported (Dietz et al. 2000), suggesting that selenium in excess can reduce the potential threat of mercury poisoning.

Although in some samples, concentrations of lead, mercury and selenium found in the blood are well above the level associated with adverse and toxic effects described in the liver and kidney for birds (Burger \& Gochfeld 2002), direct evidence of mortality of giant petrels from Bird Island associated with contamination was not detected, since it is rare to find dead adults on Bird Island. However, the wintering area of northern giant petrels predisposes this species, and particularly females, due to their more pelagic habits towards interactions with inshore pollutants. Indeed, the Patagonian shelf is an important area sustaining several globally threatened seabird and mammal species breeding in subantarctic waters (Croxall \& Wood 2002), thus chemical discharges in this area should lead to conservation concerns.

Acknowledgements. This study was partially funded by the Training and Mobility Programme of the European Commission (ERBFMBICT983030), the Ministerio de Ciencia y Tecnología (RyC 2001) and Grant BOS2000-0596-CO2-01, the British Antarctic Survey and the Universitat de Barcelona. We thank John Croxall and Peter H. Becker for suggestions on a first draft of the manuscript and Dirk Briggs for the logistic support. We are grateful also to Rocio Moreno for helping in analytical tasks. 


\section{LITERATURE CITED}

Bearhop S, Waldron S, Thompson DR, Furness RW (2000) Bioamplification of mercury in great skua Catharacta skua chicks: the influence of trophic status as determined by stable isotope signatures of blood and feathers. Mar Pollut Bull 40:181-185

Becker PH, González-Solís J, Behrends B, Croxall J (2002) Feather mercury levels in seabirds at South Georgia: influence of trophic position, sex and age. Mar Ecol Prog Ser 243:261-269

BirdLife International (2000) Threatened birds of the world. Lynx Editions, Barcelona

Bowles D (1999) An overview of the concentrations and effects of metals in cetacean species. J Cetacean Res Manag Spec Issue 1:125-148

Braune BM, Donaldson GM, Hobson KA (2001) Contaminant residues in seabird eggs from the Canadian Arctic. Part I. Temporal trends 1975-1998. Environ Pollut 114:39-54

Burger J, Gochfeld M (1997) Age differences in metals in the blood of herring (Larus argentatus) and Franklin's (Larus pipixcan) gulls. Arch Environ Contam Toxicol 33:436-440

Burger J, Gochfeld M (2002) Effects of chemicals and pollution on seabirds. In: Schreiber EA, Burger J (eds) Biology of marine birds. CRC Press, Boca Raton, FL, p 485-524

Croxall JP, Wood AG (2002) The importance of the Patagonian Shelf for top predator species breeding at South Georgia. Aquat Conserv: Mar Freshw Ecosyst 12:101-118

de Moreno JE, Gerpe MS, Moreno VJ, Vodopivez C (1997) Heavy metals in Antarctic organisms. Polar Biol 17:131-140

Dietz R, Riget F, Born EW (2000) An assessment of selenium to mercury in Greenland marine animals. Sci Total Environ 245:15-24

Franson JC (1996) Interpretation of tissue lead residues in birds other than waterfowl. In: Beyer N, Heinz GH, Redman-Norwood AW (eds) Environmental contaminants in wildlife. Interpreting tissue concentrations. CRC Press, Boca Raton, FL, p 265-279

Furness RW (1993) Birds as monitors of pollutants. In: Furness RW, Greenwood JJD (eds) Birds as monitors of environment change. Chapman \& Hall, London, p 86-143

Gerpe MS, de Moreno JE, Moreno VJ, Patat ML (2000) Cadmium, zinc and copper accumulation in the squid Illex argentinus from the Southwest Atlantic Ocean. Mar Biol 136:1039-1044

González-Solís J, Croxall JP, Wood AG (2000a) Foraging partitioning between giant petrels Macronectes spp. and its relationship with breeding population changes at Bird Island, South Georgia. Mar Ecol Prog Ser 204:279-288

González-Solís J, Croxall JP, Wood AG (2000b) Sexual dimorphism and sexual segregation in foraging strategies of northern giant petrels Macronectes halli during the incubation period. Oikos 90:390-398

González-Solís J, Afanasyev V, Briggs DR, Croxall JP, Roberts DR (2001) Wintering areas of giant petrels tracked by light level geolocation. Third Conf Eur Ornithol Union, Groningen, p 53

González-Solís J, Croxall JP, Briggs DR (2002) Activity patterns of giant petrels Macronectes spp. using different foraging strategies. Mar Biol 140:197-204

Heinz GH (1996) Selenium in birds. In: Beyer N, Heinz GH, Redman-Norwood AW (eds) Environmental contaminants in wildlife. Interpreting tissue concentrations. CRC Press, Boca Raton, FL, p 447-458

Honda K, Yamamoto Y, Tatsukawa R (1987) Distribution of heavy metals in Antarctic marine ecosystem. Proc NIPR Symp Polar Biol 1:184-197
Hunter S (1983) The food and feeding of the giant petrels Macronectes halli and M. giganteus at South Georgia. J Zool (Lond) 200:521-538

Hunter S (1984) Moult of the giant petrels Macronectes halli and M. giganteus at South Georgia. Ibis 126:119-132

Hunter S (1985) The role of giant petrels in the Southern Ocean ecosystem. In: Siegfried WR, Laws RM, Condy PR (eds) Antarctic nutrient cycles and food webs. SpringerVerlag, Berlin, p 534-542

Hunter S (1987) Species and sexual isolation mechanisms in sibling species of giant petrels Macronectes. Polar Biol 7: 295-301

Hunter S, Brooke ML (1992) The diet of giant petrels Macronectes spp. at Marion Island, Southern Indian Ocean. Colon Waterbirds 15:56-65

Jouventin P, Weimerskirch H (1990) Satellite tracking of wandering albatrosses. Nature 343:746-748

Kahle S, Becker PH (1999) Bird blood as bioindicator for mercury in the environment. Chemosphere 39:2451-2457

Kim EY, Saeki K, Tanabe S, Tanaka H, Tatsukawa R (1996) Specific accumulation of mercury and selenium in seabirds. Environ Pollut 94:261-265

Klomp NI, Schultz MA (2000) Short-tailed shearwaters breeding in Australia forage in Antarctic waters. Mar Ecol Prog Ser 194:307-310

Lewis SA, Becker PH, Furness RW (1993) Mercury levels in eggs, tissues and feathers of herring gulls Larus argentatus from the German Wadden sea coast. Environ Pollut 80:293-299

Malcolm HM, Boyd IL, Osborn D, French MC, Freestone P (1994) Trace metals in Antarctic fur seal (Arctocephalus gazella) livers from Bird Island, South Georgia. Mar Pollut Bull 28:375-380

Monteiro LR, Furness RW (1995) Seabirds as monitors of mercury in the marine environment. Water Air Soil Pollut 80:851-870

Monteiro LR, Furness RW (2001) Kinetics, dose-response, and excretion of Methylmercury in free-living adult Cory's shearwaters. Environ Sci Technol 35:739-746

Monteiro LR, Granadeiro JP, Furness RW (1998) Relationship between mercury levels and diet in Azores seabirds. Mar Ecol Prog Ser 166:259-265

Muirhead SJ, Furness RW (1988) Heavy metal concentrations in the tissues of seabirds from Gough island, South Atlantic Ocean. Mar Pollut Bull 19:278-283

Norheim G (1987) Levels and interactions of heavy metals in sea birds from Svalbard and the Antarctic. Environ Pollut 47:83-94

Pain DJ (1996) Lead in waterfowl. In: Beyer N, Heinz GH, Redman-Norwood AW (eds) Environmental contaminants in wildlife. Interpreting tissue concentrations. CRC Press, Boca Raton, FL, p 251-264

Prince PA, Croxall JP, Trathan PN, Wood AG (1998) The pelagic distribution of South Georgia albatrosses and their relationships with fisheries. In: Robertson G, Gales R (eds) Albatross biology and conservation. Surrey Beatty \& Sons, Chipping Norton, p 137-167

Rodhouse PG, Elvidge CD, Trathan PN (2001) Remote sensing of the global light-fishing fleet: an analysis of interactions with oceanography, other fisheries and predators. Adv Mar Biol 39:261-303

Rootes DM (1988) The status of birds at Signy Island, South Orkney Islands. Br Antarct Surv Bull 80:87-119

Sanpera C, Morera M, Ruiz X, Jover L (2000) Variability of mercury and selenium levels in clutches of Audouin's gulls (Larus audouinii) breeding at the Chafarinas Islands, Southwest Mediterranean. Arch Environ Contam Toxicol 39:119-123 
SCAR (1992) Status and trends of Antarctic and sub-Antarctic seabirds. Rep 11th Meeting Sci Comm Conserv Antarct Mar Living Resour 443-461

Stewart FM, Thompson DR, Furness RW, Harrison N (1994) Seasonal variation in heavy metal levels in tissues of common guillemots, Uria aalge from Northwest Scotland. Arch Environ Contam Toxicol 27:168-175

Stewart FM, Phillips RA, Bartle JA, Craig J, Shooter D (1999) Influence of phylogeny, diet, moult and sex on heavy metal concentrations in New Zealand Procellariiformes. Mar Ecol Prog Ser 178:295-305

Thompson DR (1990) Metal levels in marine vertebrates. In: Furness RW, Rainbow PS (eds) Heavy metals in the marine environment. CRC Press, Boca Raton, FL, p 143-181

Walsh PM (1990) The use of seabirds as monitors of heavy metals in the marine environment. In: Furness RW, Rain-

Editorial responsibility: Otto Kinne (Editor),

Oldendorf/Luhe, Germany bow PS (eds) Heavy metals in the marine environment. CRC Press, Boca Raton, FL, p 183-204

Waugh SM, Weimerskirch H, Cherel Y, Shankar U, Prince PA, Sagar PM (1999) Exploitation of the marine environment by two sympatric albatrosses in the Pacific Southern Ocean. Mar Ecol Prog Ser 177:243-254

Weimerskirch H, Robertson G (1994) Satellite tracking of light-mantled sooty albatrosses. Polar Biol 14:123-126

Weimerskirch H, Doncaster C, Cuenot-Chaillet F (1994) Pelagic seabirds and the marine environment: foraging patterns of wandering albatrosses in relation to prey availability and distribution. Proc R Soc Lond B 255:91-97

Woehler EJ, Johnstone GW (1991) Status and conservation of the seabirds of the Australian Antarctic Territory. In: Croxall JP (ed) Seabird status and conservation: a supplement. ICBP, Cambridge, p 279-308

Submitted: March 25, 2002; Accepted: July 16, 2002

Proofs received from author(s): October 29, 2002 